\title{
Pengaruh pengkayaan Daphnia sp. menggunakan astaxanthin terhadap kualitas warna merah ikan Cupang Halfmoon (Betta splendens, Regan 1910)
}

\section{Effect of the enrichment of Daphnia sp. with astaxanthin on the red color quality of Halfmoon Betta Fish (Betta splendens Regan, 1910)}

\author{
Dony Prasetyo $^{\left.1)^{*}\right)}$, Hany Handajani ${ }^{1)}$, David Hermawan ${ }^{1)}$, Iqbal Fuhaira ${ }^{1)}$ \\ ${ }^{1)}$ Program Studi Akuakultur, Fakultas Pertanian-Peternakan, Universitas Muhammadiyah Malang, Indonesia \\ Corresponding author ${ }^{*}$ : donyprasetyo@umm.ac.id
}

\begin{abstract}
Betta fish is one of the ornamental fish culture commodities that has an attractiveness and economic value that is influenced by the quality of body color. The purpose of this study was to determine the effect of the enrichment of the live feed with astaxanthin Carophyll ${ }^{\odot}$ red on the quality of red color of red Betta Fish Halfmoon and to find out the percent concentration of astaxanthin that gives an optimal value for the color of betta fish. The research method used was completely randomized design method (CRD) with a dose of astaxanthin treatment enriched in Daphnia sp. with 5 treatments and 5 replications; $0 \mathrm{~g} \mathrm{~L}^{-1}$ (control), $0.25 \mathrm{~g} \mathrm{~L}^{-1}, 0.5 \mathrm{~g} \mathrm{~L}^{-1}, 0.75 \mathrm{~g} \mathrm{~L}^{-1}$ and $1 \mathrm{~g} \mathrm{~L}^{-1}$. The fish used is Betta fish Halfmoon with uniform red color. Observations were made for 30 days including the color quality (intensity and brightness) using a Color reader Minolta CR-20, the calculation of the amount of Daphnia sp. consumed during culture period, length and weight gain and water quality. Astaxanthin enrichment in Daphnia sp. at a dose of 0.25 to $0.5 \mathrm{~g} \mathrm{~L}^{-1}$ can increase the intensity and brightness of red color in halfmoon betta fish, but the color increase was temporary. Astaxanthin contained in Daphnia sp. increase the amount of feed consumption.
\end{abstract}

Keywords: Astaxanthin, Betta fish, Color reader, Red pigment.

\begin{abstract}
ABSTRAK
Ikan Cupang merupakan salah satu komoditi budidaya ikan hias yang mempunyai daya tarik dan nilai ekonomis dipengaruhi oleh kualitas warna tubuh. Tujuan dari penelitian ini adalah untuk mengetahui pemberian pakan hidup yang diperkaya dengan astaxanthin Carophyll $^{\odot}$ red dapat meningkatkan kualitas warna merah pada ikan Cupang Halfmoon merah serta untuk mengetahui persen konsentrasi Carophyll ${ }^{\odot}$ red yang memberikan nilai optimal bagi warna ikan cupang. Metode penelitian yang digunakan adalah menggunakan metode rancangan acak lengkap (RAL) dengan perlakuan dosis Carophyll ${ }^{\odot}$ red yang diperkaya melalui Daphnia sp. dengan 5 perlakuan 5 ulangan : $0 \mathrm{~g}$ (kontrol); $0,25 \mathrm{~g} \mathrm{~L}^{-1} ; 0,5 \mathrm{~g} \mathrm{~L}^{-1} ; 0,75 \mathrm{~g} \mathrm{~L}^{-1}$ dan $1 \mathrm{~g} \mathrm{~L}^{-1}$. Ikan yang digunakan adalah ikan Cupang Halfmoon dengan warna yang seragam. Pengamatan yang dilakukan selama 30 hari meliputi kualitas warna (intensitas dan kecerahan) yang dilakukan dengan menggunakan alat Color reader Minolta CR-20, perhitungan jumlah konsumsi Daphnia sp. selama pemeliharaan, pertumbuhan panjang, bobot yang dihasilkan dan kualitas air. Pengkayaan astaxanthin melalui Daphnia sp. pada dosis 0,25 sampai $0,5 \mathrm{~g} / \mathrm{L}$ dapat meningkatkan secara signifikan intensitas dan kecerahan warna merah pada ikan Cupang Halfmoon, namun peningkatan warna bersifat semetara. Astaxanthin yang terkandung dalam Daphnia sp. meningkatkan jumlah konsumsi pakan.
\end{abstract}

Kata Kunci: Astaxanthin, Color reader, Cupang, Pigmen merah.

DOI: http://dx.doi.org/10.33772/jspi.v4n1 


\section{PENDAHULUAN}

Indonesia merupakan salah satu eksportir terbesar ikan hias, baik yang berasal dari laut maupun tawar. Produksi ikan hias Indonesia terus meningkat $9 \%$ per tahun mulai dari 945,3 juta ekor di tahun 2011 hingga mencapai sekitar 1 miliar ekor di tahun 2015 (Weningsari, 2013). Ikan Cupang berada diurutan kedua setelah ikan hias botia yaitu dengan nilai penjualan sebanyak 22.650 ekor. Data tersebut berdasarkan hasil Lalu Lintas Ikan Ekspor di Stasiun Karantina Ikan Kelas 1 Sultan Thaha Provinsi Jambi pada tahun 2010 (KKP, 2011).

Berbeda dengan ikan konsumsi, ikan hias memiliki pesona tersendiri untuk menarik minat konsumen/penghobi. Warna yang indah dan cerah menjadi pesona ikan hias dan menentukan nilai jualnya. Ikan Cupang Halfmoon merupakan salah satu jenis ikan yang memiliki pesona tersendiri dikarenakan warna yang indah pada ekornya maupun tubunya (Mardya et al., 2016).

Beberapa kendala dihadapi oleh pembudidaya ikan cupang, seperti kualitas warna kurang baik, pertumbuhan yang masih rendah, dan berbagai penyakit yang biasa menyerang selama budidaya (Budi et al., 2013). Ada berbagai cara dalam meningkatkan kualitas warna, yaitu dengan penambahan pigmen melalui pakan (Sitorus, 2015). Pigmen yang digunakan dapat menggunakan pigmen sintetik maupun pigmen alami. Pemberian pigmen alami menghasilkan peningkatan warna yang lebih baik jika dibandingkan dengan pigmen sintetik (Barus et al., 2014).

Teknik manipulasi pigmen merupakan salah satu cara yang dilakukan untuk mendapatkan warna indah dan cerah pada ikan cupang, yaitu dengan cara memperkaya kandungan sel pigmen dalam tubuh ikan melalui pemberian pakan yang mengandung karetenoid, astaxanthin $\left(\right.$ Carophyll ${ }^{{ }^{\odot}}$ red). Pigmen merah astaxanthin telah diujikan diberbagai komoditi seperti ikan Badut (Yulianti et al., 2014), maskoki (Weeratunge dan Perera, 2016), ikan Mas (Jagruthi et al., 2014), dan Discus (Song et al., 2016). Pemanfaatan astaxanthin untuk meningkat warna pada ikan Cupang Halfmoon warna merah belum pernah dilakukan. Oleh karena itu, penelitian ini dimaksudkan untuk mengkaji pengaruh pemberian astaxanthin Carophyll $^{\odot}$ red dengan dosis berbeda melalui pengkayaan pada Daphnia sp. untuk meningkatkan kualitas warna ikan Cupang Halfmoon.

\section{METODE PENELITIAN}

Penelitian dilakukan di Laboratorium Perikanan Fakultas Pertanian-Peternakan (FPP) serta Laboratorium Ilmu Teknologi Pangan Universitas Muhammadiyah Malang pada bulan Juni-Agustus 2019. Bahan yang digunakan selama penelitian meliputi ikan Cupang Halfmoon merah berjenis kelamin jantan. Astaxanthin dengan merk Carophyll ${ }^{\odot}$ red, Daphnia sp. Wadah penelitian berupa akuarium $10 \times 10 \times 10 \mathrm{~cm}$, Color reader Conica Minolta CR-20, timbangan analitik, aerator set ASC 89031.

Penelitian ini menggunakan Rancangan Acak Lengkap (RAL) dengan 5 perlakuan dan 10 kali ulangan individu. Daphnia sp. diperkaya dengan cara direndam pada larutan Carophy $11^{\odot}$ red dengan dosis 0 $\mathrm{g} \mathrm{L}^{-1}, 0,25 \mathrm{~g} \mathrm{~L}^{-1} ; 0,5 \mathrm{~g} \mathrm{~L}^{-1} ; 0,75 \mathrm{~g} \mathrm{~L}^{-1}$, dan $1 \mathrm{~g} \mathrm{~L}^{-1}$. Data perubahan nilai intensitas dan kecerahan warna, jumlah konsumsi pakan, kelangsungan hidup dan kualitas air dianalisis varian (ANOVA). Apabila terdapat perbedaan signifikan antar perlakuan maka dilakukan uji lanjut Beda Nyata Terkecil (BNT) dengan taraf $5 \%$. Penelitian ini diawali dengan mempersiapkan wadah penelitian berupa akuarium persegi sebanyak 50 buah yang telah dibersihkan serta perlengkapan lainnya seperti aerasi, dan pengisian air yang diendapkan selama 24 jam. Ikan Cupang Halfmoon jantan dengan warna merah seragam sebanyak 50 ekor didapatkan dari petani di Pandaan. Setiap akuarium diisi 1 ekor ikan Cupang. Carophyll ${ }^{\odot}$ red sesuai dosis perlakuan dilarutkan dalam 1 Liter air, kemudian Daphnia sp. ditebar pada larutan tersebut selama 15 menit untuk pengkayaan. Kualitas air diamati setiap hari meliputi parameter suhu, DO, dan $\mathrm{pH}$.

Ikan Cupang Halfmoon diberi pakan Daphnia sp. yang telah diperkaya sesuai dosis selama 21 hari. Kemudian hari ke 21 sampai hari ke 30 diberi pakan Daphnia sp. tanpa pengkayaan untuk mengetahui pengaruh pewarnaan pascaperlakuan. Pemberian pakan dilakukan sekenyang-kenyangnya, tiga kali sehari. Pengukuran warna dilakukan setiap 10 hari sekali, pada bagian badan ikan. Jumlah konsumsi pakan dan pengamatan kualitas air dilakukan setiap hari. Data kelulushidupan ikan cupang diukur pada akhir penelitian. 
34 Prasetyo, et al.

JURNAL SAINS dan INOVASI PERIKANAN / Journal of Fishery Science and Innovation

Vol. 4, No. 1, 32-37, Januaari 2020
Colour reader Minolta CR-20 merupakan alat untuk mengukur warna suatu permukaan bidang datar. Nilai yang muncul saat pengambilan data dengan colour reader yaitu $\mathrm{L}^{*}$ (Kecerahan - gelap), $\mathrm{a}^{*}$ (merah - hijau) dan $\mathrm{b}^{*}$ (kuning - biru). Pengukuran nilai kecerahan $\mathrm{L}^{*}$ berkisar antara 0-100 dimana nilai kecerahan turun (-) maka semakin gelap nilai warna yang didapatkan namun jika nilai naik $(+)$ maka semakin cerah warna yang didapat. Nilai $a^{*}$ berkisar antara \pm 128 dimana semakin turun (-) maka semakin hijau warna yang didapat, namun jika nilai $a^{*}$ naik (+) maka semakin merah warna yang didapat. Nilai $b^{*}$ berkisar antara \pm 128 dimana semakin turun (-) maka semakin kuning warna yang didapat namun jika nilai $b^{*}(+)$ meningkat maka semakin biru warna yang didapat.

\section{Intensitas Warna Merah}

Berdasarkan hasil pengukuran intensitas warna merah pada badan ikan Cupang selama pemeliharaan yaitu dengan menggunakan Colour reader, didapat nilai intensitas warna merah seperti pada Gambar 1.

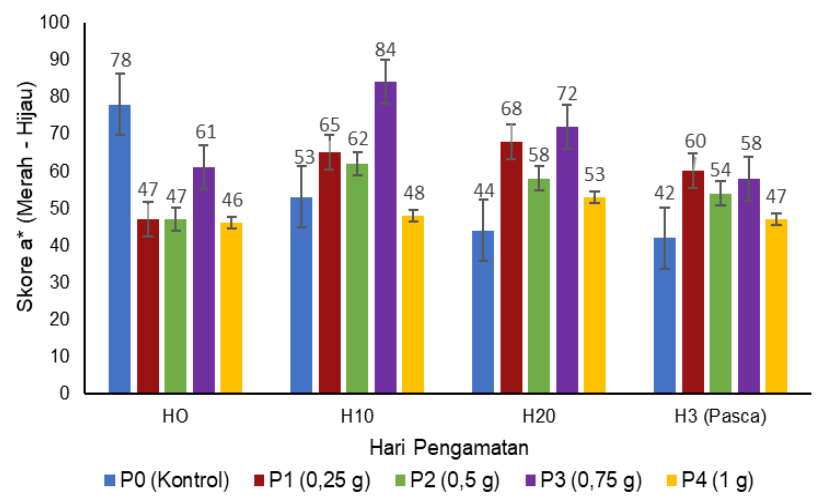

Gambar 1. Intensitas warna merah pada badan ikan Cupang

Data pada H0 menunjukkan bahwa meski hewan uji telah dipilih secara cemat agar homogen namun tetap terdapat perbedaan nilai intensitas warna merah pada saat sebelum perlakuan. Hewan uji disetiap perlakuan mengalami perbahan intensitas warna merah dari awal (H0) hingga akhir perlakuan (H20) dan pascaperlakuan (H30). P0 (kontrol) mengalami trend penurunan warna, sedangkan P1, P2, P3 dan P4 mengalami trend peningkatan warna hingga $\mathrm{H} 20$, kemudian terjadi penurunan pada $\mathrm{H} 30$. Uji sidik ragam menunjukkan terdapat perbedaan signifikan nilai intensitas warna merah pada P1, P2 dan P3.

\section{Kecerahan Warna Merah}

Pengujian warna dengan color reader menggunakan skala kecerahan suatu objek, sehingga semakin rendah nilai yang didapat maka semakin gelap warna yang dihasilkan. Hasil pengamatan warna badan ikan Cupang selama pemeliharaan dapat dilihat pada Gambar 2.

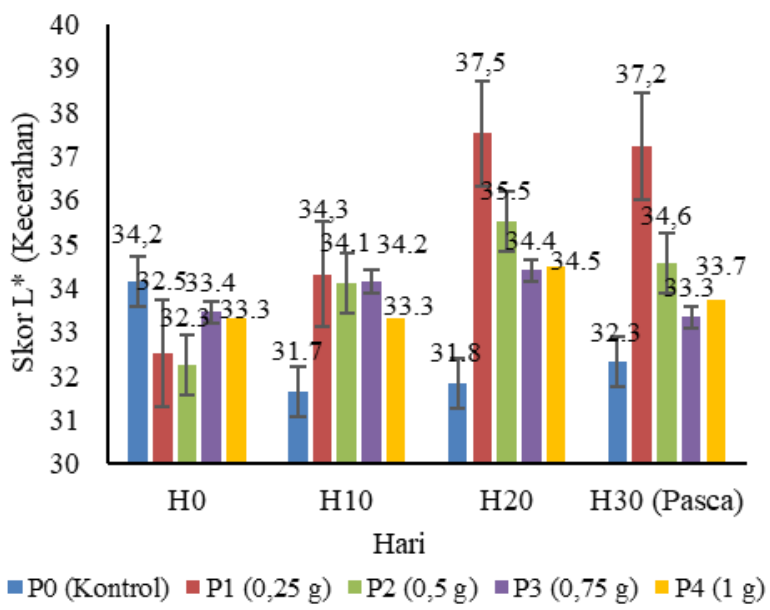

Gambar 2. Nilai kecerahan warna merah

Data kecerahan juga menunjukkan trend peningkatan dari awal perlakuan (H0) hingga akhir perlakuan (H20), kemudian menurun pada saat pasca perlakuan (H30). Nilai peningkatan nilai kecerawan warna tertinggi terdapat pada P1. Sedangkan P0 (kontrol) mengalami penurunan nilai kecerahan.

\section{Jumlah Konsumsi Pakan}

Jumlah konsumsi pakan oleh ikan menunjukkan banyaknya Daphnia sp. yang dikonsumsi tiap ekor ikan Cupang selama pemeliharaan. Gambar 3. ratarata total Daphnia sp. yang dikonsumsi selama pemeliharaan. Jumlah konsumsi Daphnia sp. berbeda signifikan antara kontrol dan perlakuan. Dimana ikan lebih banyak mengkonsumsi Daphnia sp. yang diperkaya dengan pigmen.

\section{Parameter Kualitas Air}

Kualitas air diamati selama perlakuan (Tabel 1) menunjukkan rata-rata nilai suhu, $\mathrm{pH}$ dan DO. Data kualitas air menunjukkan tidak terdapat perbedaan yang signifikan pada atau dapat dikatakan parameter kualitas air selama pemeliharaan stabil. 


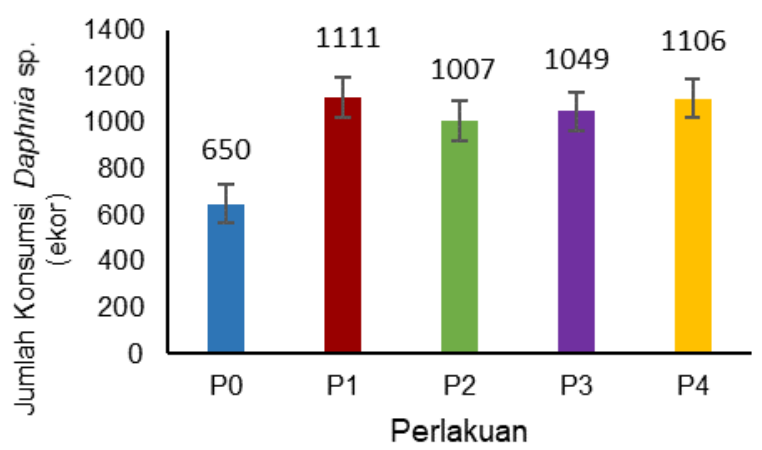

Gambar 3. Jumlah konsumsi Daphnia

Tabel 1. Kualitas Air

\begin{tabular}{ccccc}
\hline \multirow{2}{*}{ Perlakuan } & \multicolumn{3}{c}{ Rata-rata parameter kualitas air } & \multirow{2}{*}{ SR (\%) } \\
\cline { 2 - 4 } & Suhu $\left({ }^{\circ} \mathrm{C}\right)$ & $\mathrm{pH}$ & $\mathrm{DO}(\mathrm{mg} / \mathrm{L})$ & \\
\hline P0 & $26 \pm 2,4$ & $6,8 \pm 2,4$ & $6 \pm 0,6$ & 100 \\
P1 & $26 \pm 2,4$ & $7,4 \pm 1,4$ & $5,6 \pm 0,4$ & 100 \\
P2 & $26 \pm 2,3$ & $7,4 \pm 1,2$ & $6 \pm 0,3$ & 100 \\
P3 & $26 \pm 2,1$ & $6,7 \pm 0,7$ & $5,8 \pm 0,5$ & 100 \\
P4 & $26,4 \pm 2$ & $6,8 \pm 1,5$ & $5,8 \pm 0,6$ & 100 \\
\hline Kisaran & $24-30$ & $6,5-7,2$ & $\geq 5$ & \\
Optimum* & & &
\end{tabular}

\section{Pembahasan}

Pada penelitian ini terdapat perbedaan diantara beberapa perlakuan yang diujikan. Nilai pengujian warna dengan menggunakan Color reader Minolta CR-20 menunjukkan bahwa P0 (kontrol) yang diberi pakan Daphnia sp. tanpa pengkayaan mengalami penurunan intensitas warna pada tubuh ikan selama pemeliharaan. Ikan Cupang yang hanya diberi pakan Daphnia sp. selama 10 hari akan mengalami penurunan warna, diduga karena kandungan nutrisi pada Daphnia sp. tidak cukup untuk menjaga kualitas warna ikan Cupang Halfmoon khususnya pembetukan pigmen merah. Sedangkan ikan Cupang yang diberi Daphnia sp. yang diperkaya (P1, P2, P3 dan P4) intensitas warna merah tidak menurun bahkan sebagian meningkat. Hal ini menunjukkan pengkayaan Carophyll $^{\odot}$ red yang mengandung Astaxanthin dapat menjaga bahkan meningkatkan proses pigmentasi warna merah pada tubuh ikan Cupang Halfmoon. Menurut Ambati et al. (2014), astaxanthin mengandung senyawa aktif 10 kali lipat dibandingkan senyawa aktif lain untuk perubahan warna ikan.
Ikan Cupang yang dipeliharan dalam waktu tertentu dan hanya diberi makan Daphnia sp. mengalami penurunan warna oleh karena kebutuhan karotennya tidak tercukupi. Menurut Utomo dkk, (2006) menyatakan kebutuhan karotenoid pada ikan muda relatif lebih sedikit dibandingkan dengan ikan dewasa karena perubahan warna tubuhnya belum tetap. Ikan dewasa membutuhkan kadar karotenoid yang cukup untuk menunjang pembentukan warna tubuhnya.

Selain intensitas warna, kecerahan warna juga mempengaruhi warna yang tampak. Kecerahan warna yang ditunjukkan sebagai nilai $\mathrm{L}^{*}$ terdapat perbedaan signifikan antara perlakuan dan kontrol (Gambar 2). Ikan kontrol (P0) yang hanya diberi pakan Daphnia sp. tanpa pengkayaan mengalami penurunan nilai kecerahan warna selama pemeliharaan. Sedangkan ikan Cupang yang mengkonsumsi Daphnia sp. yang mengandung sejumlah karotenoid dapat meningkatkan kualitas kecerahan warna pigmen yang terdapat pada epitel tubuh. Nampak pada P1 dan P2 nilai kecerahan warna meningkat dari awal perlakuan yaitu H0 hingga akhir perlakuan H20. Gouveia et al., (2003), melaporkan bahwa pemberian Chlorella vulgaris, Haemotococcus pluvialis, Arthrospira maxima (spirulina) dan astaxantin sintetis dalam pakan mampu mempengaruhi nilai lightness $\left(\mathrm{L}^{*}\right)$ pada kulit ikan koi dan mas koki. Hal ini diperkuat juga dengan pernataan Sukarman, et al., (2014), astaxantin memiliki kecenderungan menghasilkan nilai Hue (campuran warna dasar merah, hijau, biru, kuning) yang lebih baik, hal tersebut karena astaxantin secara langsung dapat tersimpan dalam jaringan tubuh ikan tanpa mengalami perubahan struktur kimia.

Peningkatan intensitas dan kecerahan warna ikan Cupang hanya terjadi pada saat pemberian perlakuan atau pada saat penambahan Astaxanthin masih terjadi yaitu dari H0 sampai H20. Sedangkan pasca perlakuan pada $\mathrm{H} 20$ sampai $\mathrm{H} 30$, intensitas dan kecerahan warna tubuh cenderung kembali menurun. Hal ini terjadi karena kandungan Daphnia sp. tidak cukup menunjang kestabilan warna ikan Cupang Halfmoon selama permeliharaan. Sehingga dengan adanya penambahan Astaxanthin pada pakan, kebutuhan ikan akan karotenoid terpenuhi dan cukup untuk menunjang kestabilan warna, bahkan meningkatkan intensitas dan kecerahannya, namun peningkatan tersebut bersifat sementara. Ikan Cupang yang kembali diberikan pakan tanpa pengkayaan 
karotenoid, intensitas dan kecerahan tubuhnya kembali menurun.

Jumlah pakan yang dikonsumsi oleh ikan terdapat perbedaan yang signifikan antara kontrol dan perlakuan, dimana ikan Cupang Halfmoon perlakuan mengkonsumsi Daphnia sp. lebih banyak dibandingkan ikan Cupang kontrol (Gambar 3). Perbedaan jumlah konsumsi lebih dipengaruhi karena adanya perbedaan warna pada Daphnia sp. Astaxanthin yang diserap oleh Daphnia sp. menjadikanya berwarna merah sehingga lebih mudah terlihat oleh ikan Cupang Halfmoon. Ikan Cupang yang dalam perilaku berburunya masih mengandalkan indra penglihatan dapat melihat objek/Daphnia sp. lebih baik karena adanya pigmen warna tersebut. Sehingga lebih banyak Daphnia sp. yang tertangkap dan dikonsumsi. Menurut Melianawati et al., (2012) tingkat konsumsi pakan akan ditentukan oleh ketersediaan pakan alami, kesesuaian jenis dan ukuran. Pakan yang sesuai akan memberikan energi yang cukup untuk metabolisme, pertumbuhan bahkan pigmentasi warna.

Pada penelitian ini juga diukur laju pertumbuhan ikan Cupang Halfmoon, namun hasil menunjukkan bawah tidak terdapat perubahan bobot dan panjang yang signifikan antara $\mathrm{H} 0$ dan H30. Cupang yang diberikan pakan yang tidak diperkaya ataupun diperkaya dengan astaxanthin tidak dapat meningkatkan pertumbuhan ikan Cupang. Hal ini disebabkan ikan uji yang digunakan sudah dalam stadia dewasa yang tidak lagi mengalami pertumbuhan secara signifikan. Selain itu kebutuhan nutrisi untuk tumbuh diduga tidak cukup jika hanya didapatkan dari Daphnia sp. yang dikonsumsi selama pemeliharaan. Hal ini didukung oleh Yandes et al., (2003) menyatakan bahwa pertumbuhan dapat terjadi jika terdapat kelebihan energi untuk metabolisme basal, pencernaan, osmoregulasi, perbaikan sel/jaringan serta untuk beraktifitas. Pakan yang memenuhi nilai gizi akan sangat terlihat performasi yang dihasilkan. Hal tersebut membuktikan bahwa ikan mampu memanfaatkan pakan yang diberikan untuk pemeliharaan tubuh maupun pertumbuhan.

Kelangsungan hidup selama penelitian baik pada kontrol maupun perlakuan memiliki nilai sebesar 100 $\%$. Hal ini menunjukkan bahwa pemberian pigmen sistetis Astaxanthin melalui Daphnia sp. tidak mempengaruhi kelulushidupan hewan uji, disamping parameter air selalu optimum dan stabil selama pemeliharaan. Bahkan menurut Liu et al. (2016) pemberian astaxanthin dapat meningkatkan kelulushidupan ikan Pelteobagrus fulvidraco yang terinfeksi Proteus mirabilis.

Hasil pengukuran $\mathrm{pH}$ air di semua perlakuan menunjukkan nilai rata-rata $\mathrm{pH}$ sebesar 6,8 sampai 7,4 yang artinya masih dalam kisaran optimum. Agus dkk (2010), menyatakan besarnya $\mathrm{pH}$ air yang sesuai dengan kebutuhan ikan Cupang adalah 6,5 sampai 7,2 . Tingkat keasaman $(\mathrm{pH})$ pada kisaran ini baik dan cukup ideal untuk pertumbuhan ikan cupang karena pada keadaan ini ikan cupang tumbuh dengan baik dan $\mathrm{pH}$ optimum untuk pertumbuhan ikan adalah berkisar dari 7 - 8 (Nugroho et al., 2016).

Oksigen terlarut selama pemeliharaan berada pada kisaran 5 hingga $7 \mathrm{mg} / \mathrm{L}$. DO dalam air sangat diperlukan dalam proses respirasi. Kandungan DO yang rendah akan memperlambat laju pertumbuhan. Agar performa pertumbuhan maksimal maka DO harus dipertahankan diatas $5 \mathrm{mg} / \mathrm{L}$. (Nugroho et al., 2016). Nilai rata suhu pada penelitian ini adalah 26,4 ${ }^{\circ} \mathrm{C}$. Nilai tersebut masih dalam kisaran optimum suhu pada pemeliharaan ikan Cupang(Agus et al., 2010).

\section{KESIMPULAN}

Berdasarkan hasil penelitian dapat disimpulkan bahwa pemberian Daphnia sp. yang diperkaya Carophyll ${ }^{\odot}$ red yang mengandung astaxathin dengan dosis perendaman 0,25-0,5 $\mathrm{g} / \mathrm{L}$ efektif untuk peningkatan warna merah ikan Cupang Halfmoon, namun peningkatan warna tersebut bersifat sementara. Pengkayaan warna tersebut juga dapat meningkatkan jumlah konsumsi Daphnia sp.

\section{DAFTAR PUSTAKA}

Agus M, Yusufi T, Nafi B. 2010. Pengaruh perbedaan jenis pakan alami daphnia, jentik nyamuk dan cacing sutera terhadap pertumbuhan ikan Cupang hias Betta splendens. Pena Akuatika 2 (1): 21-29.

Ambati RR, Phang SM, Ravi S, Aswathanarayana RG. 2014. Astaxanthin: sources, extraction, stability, biological activities and its commercial applications-a review. Marine Drugs 12 (1): 128-152.

Barus, Suranta R, Usman, Syammaun, Nurmatias, Nurmatias. 2014. Pengaruh kon-sentrasi tepung Spirulina platensis pada pakan terhadap peningkatan warna ikan Maskoki (Carassius auratus). Aquacoastmarine 5(4).

Budi S, Intan R, Leko N, Tantu AG. 2013. Pengaruh ekstrak Cabe Merah Capasicum annum terhadap pigmentasi, kadar Leukosit dan pertumbuhan ikan 
Cupang Betta splendens pada dosis yang berbeda. Konfernsi Akuakultur Indonesia. 301-307.

Gouveia L, Rema P, Pereira O, Empis J. 2003. Colouring ornamental fish (Cyprinus carpio and Carassius auratus) with micro-algal biomass. Aquaculture Nutrition 9: 123-129.

Jagruthi C, Yogeshwari G, Anbazahan SM, Mari LSS, Arockiaraj J, Mariappan P, Sudhakar GRL, Balasundaram C, Harikrishnan R. 2014. Effect of dietary astaxanthin against Aeromonas hydrophila infection in common carp, Cyprinus carpio. Fish and Shellfish Immunology 41 (2): 674-680.

KKP (Kementrian Kelautan dan Perikanan) Stasiun Karantina Ikan Kelas I Sultan Thaha Jambi. (2001). Laporan Penyampaian Data Lalu Lintas Tahun 2010 Stasiun Karantina Ikan Kelas I Sultas Thaha Jambi. Jambi: 6 hlm.

Liu F, Shi H, Guo Q, Yu Y, Wang A, Lv F, Shen W. 2016. Effects of astaxanthin and emodin on the growth, stress resistance and disease resistance of yellow catfish (Pelteobagrus fulvidraco). Fish \& Shellfish Immunology 51: 125-135.

Mardya S, Sulmartiwi L, Andriyono S. 2017. Penambahan mikroalga merah Porphyridium Cruentum pada pakan terhadap kecerahan warna ikan Cupang (Betta splendens). Journal of Aquaculture and Fish Health 6 (1): 41-47.

Meiyana M, Minjoyo H. 2011. Pembesaran Clownfish (Amphiprion ocellaris) di bak terkendali dengan penambahan astaxanthin. Balai Besar Pengembangan Budidaya Laut. Lampung. Hal 1-8

Melianawati R, Astuti NWW, Slamet B. 2012. Pola pertumbuhan larva ikan Kerapu Raja Sunu (Plectropoma laevis) Lacepede, 1801 dan tingkat konsumsinya terhadap zooplankton rotifer (Brachionus plicatilis). Jurnal Ilmu dan Teknologi Kelautan Tropis 4: 217-228.

Nugroho RA, Manurung H, Saraswati D, Ladyescha D, Nur FM. 2016. The effects of Terminalia catappa L. leave extract on the water quality properties, survival and blood profile of ornamental fish (Betta sp.) cultured. Biosaintifika 8 (2): 240-247.

Sitorus AMG. 2015. Pengaruh konsentrasi tepung astaxanthin dalam pakan terhadap peningkatan warna ikan Maskoki (Carassius auratus). Skripsi. Program Studi Manajemen Sumberdaya Perairan USU. Medan.

Song X, Wang L, Li X, Chen Z, Liang G, Leng X. 2016. Dietary astaxanthin improved the body pigmentation and antioxidant fuction, but not the growth of discus fish (Symphysodon spp.). Aquaculture Research 48 (4): 1359-1367.
Sukarman, Hirnawati R. 2014. Alternatif karotenoid sintesis (astaxantin) untuk meningkatkan kualitas warna Ikan Koi (Carassius auratus). Widyariset 13 (3): 337-342.

Utomo NBP, Carman O, Fitriyati N. 2006. Pengaruh penambahan Spirulina platensis dengan kadar berbeda pada pakan terhadap tingkat intensitas warna merah pada ikan Koi Kohaku (Cyprinus carpio L.). Jurnal Akuakultur Indonesia 5(1): 1-4.

Weeratunge WKOV, Perera BGK. 2016. Formulation of a fish feed for goldfish with natural astaxanthin extracted from shrimp waste. Chemistry Central Journal 10 (44)

Weningsari E. 2013. Pengembangan agribisnis ikan Cupang di Kelurahan Ketami Kecamatan Pesantren Kota Kediri. Jurnal Manajemen Agribisnis 13(1).

Yandes Z, Affandi R, Mongkogita I. 2003. Pengaruh pemberian selulosa dalam pakan terhadap kondisi biologis benih ikan Gurami (Osphronemus gourami lac). Jurnal lktiologi Indonesia 3(1): 27-33.

Yulianti ES, Maharani HW, Diantari R. 2014. Efektivitas pemberian astaxanthin pada peningkatan kecerahan warna ikan Badut (Amphiprion ocellaris). E-jurnal Rekayasa dan Teknologi Budidaya Perairan 3 (1): 313-318. 